keener enterprise of our industrialists and the higher skill of our workmen. Experience of the War has shown that Great Britain is second to none in the fields of scientific discovery and invention, and industrialists have shown that they are capable of translating the results of research rapidly and efficiently into products required for the successful prosecution of the War. This high quality of research is one of the surest grounds for confidence in our ability to meet successfully the difficult times that lie ahead.

\section{Taxation and Research}

REFERENCE has been made in various recent reports on scientific research and industry to the financial aspect in its relation to taxation. Thus the London Chamber of Commerce report (see Nature, March 11, p. 294) advocates that expenditure on research should be chargeable on revenue. The matter has also been taken up by the Parliamentary and Scientific Committee, which has prepared a memorandum on the subject. This memorandum urges that the Government, in considering its taxation policy, should look to the prospect of benefiting from higher income tax returns when industry, as a result of the development, through research, of new processes and products, is made more profitable. The recommendations, however, are intended to afford a basis for discussion rather than to represent rigid and final views, and in particular the Committee wishes to learn the opinion of the revenue authorities on the practical reactions of its proposals. In general, it is recommended that the law relating to the taxation of profits should be amended so as to recognize the principle that all expenses incurred on research and development are allowable as deductions from taxable profits, with the corollary that receipts from a lease or sale of discoveries should be brought into taxable profits. It is also suggested that an allowance should be made for taxation purposes of a fixed percentage of any capital assets which have been provided solely for research purposes. The Committee also supports suggestions made by representative trade bodies to the Inland Revenue Committee regarding the amortization of business premises and machinery generally. Depreciation rates should be increased so as to include obsolescence, which has become a more important factor than wear and tear.

\section{British Radio Research Institute}

THE British Institution of Radio Engineers recommends the formation of a British Radio Research Institute, the functions of which would be the pursuit of basic research of the type that has hitherto suffered restriction owing to its high cost, absence of obvious or immediate practical applications, or the poor prospect of early financial returns. The institute should be financed by industry supplemented by a Government grant of at least equal amount. The work of the institute should be directed by a board representing Governmental authorities, the B.B.C. and the Services, the industry, the British Institution of Radio Engineers, the associated professional institutions and the universities of the Empire. In addition to a permanent scientific staff, the assistance and engagement of extra-mural workers should be arranged in co-operation with industry and the universities.

The advantages to be derived from the proposals are that the advancement of radio and electronic sciences would be freed from the limitations of restricted finance, duplication of original research work, spasmodic trade fluctuations, etc. Competitive private enterprise would be stimulated and the intake of high-grade technical personnel increased. It would remain with private enterprise to develop the practical and industrial applications of the scientific results flowing from the research institute. The pre-war hiatus between industry, the Government and scientific workers would be effectively bridged by the proposed governing board. New knowledge, carrying with it the possibility of new industries, would be continuously sought and be available for the free use of manufacturers to develop practical applications of the scientific principles. The necessity for private research departments would not be reduced; but the availability of undeveloped basic knowledge would give such departments a far greater opportunity for returning a dividend. The application of radio technique to fields other than broadcasting is capable of considerable development, and therefore the potential absorption of labour is considerable.

On the financial side, the contribution of industry to research associations was increasing before the War, and support is now being given to the principle of larger contributions being made in the future. Assuming the turnover to be only $£ 20$ million for the radio industry, an allocation of 0.25 per cent would give, with Government assistance, an income comparable with that of other research associations. If subscribing membership is open to all British industrial undertakings in the British Commonwealth which produce, manufacture or use electronic equipment, the income of the research institute would be comparable with the support given to any other association, while at the same time making the field of research inexhaustible. During the War, radio has graduated into a highly important industry. In the post-war era it should be supplying capital goods on a scale equal to many of the older industries; not only should the range and quality of its consumer goods be very different from anything known before, but also essential instruments and devices for other industries must be provided if British scientific and industrial progress is to be maintained. For all this development co-operative research is essential. It is strongly advocated by the Institution that opportunity for participation in the work of the research institute shall be provided for all countries in the British Commonwealth. Such collaboration in research will materially aid development of communications and the prosperity of the entire Empire.

\section{Fuel for Household Use}

ON February $18 \mathrm{Mr}$. J. G. Bennett, addressing the Fuel Luncheon Club in London on "The Future of Coal for Small-Scale Uses", compared raw coal, town's gas and electricity for household space heating. The comparison was based on heat costs incurred in production and distribution and the efficiency in use of gas and electricity when these are produced from cotl. The results for all three, with appliances of current type, turned out to be identical -16 per cent of the heating value of the coal. Developments anticipated in appliances were estimated to increase these figures to 45 per cent for coal burnt in open fires, 24 per cent for gas and 33 per cent for electricity. Some may read into these figures the implication that no fuel-saving can be expected from the processing of coal before use. It should, however, be recalled that coal-less countries import 